\title{
MORPHOMETRIC STUDY ON PRE- AND POST-HATCHING NERVE CELL BODIES OF LUMBAR SPINAL GANGLIA OF GALLUS DOMESTICUS
}

\author{
CLAUDIO A. FERRAR DE CARVALHO * \\ CIRO F. DA SILVA ** \\ BONFIN A. SILVA JUNIOR *** \\ M. VILMA DE ARAUJO ***
}

The migration of the spinal ganglion neuron mother cells in the chick embryo, from the neural crest towards the lateral part of the neural tube, occurs during the first $21 / 2$ days of incubation $28,59,60,61$. Two different regions (ventrolateral and dorsomedial) can be described in the ganglion whose cells present distinct morphological, as well as functional features ${ }^{22}$. Similar aspects are described in humans by McKinniss ${ }^{34}$. But, as the smaller-sized cells of the dorsomedial region present a higher growing rate than those of the ventrolateral region, no histological distinction between the two regions may be observed after the 15th day of incubation. The ultrastructure of adult spinal ganglion neurons has been studied extensively by different authors $1,10,24,42,50,51$, as well as their differentiation in $G$. domesticus $43,46,57$ : up to the 5 th day of incubation the neuroblasts present scarce cytoplasm with few ribosomes and scanty developed RER; later on they start to show all the features of mature cells, i.e. well developed RER and Golgi complex, many mitochondria, and free ribosomes. Environmental influences acting on the spinal ganglion neuron were studied in embryos submitted to limb excision and grafts in order to analyse, for example, the influence of the innervation field on the number of sensory neurons 26.

The present paper reports a morphometric study looking for quantitative modifications of the fine structure of these neurons at six different ages, ranging from the 10th day of incubation to the 120th post-hatching day. We estimated the nuclear and cytoplasmic volumes and for the latter the relative volumes of hyaloplasm (including free ribosomes) inside and outside the Nissl bodies, RER, SER, mitochondria dense bodies and Golgi complex, the surface-to-volume ratio, and total surface of the organelles.

Department of Anatomy, ICB, São Paulo University: * Full Professor; ** Assistant Professor; *** Resident Senior; *** Biologist. This study was carried out with aid of grants from the CNPq (Brasil). (Processo 2222.1694/78). 


\section{MATERIAL AND METHODS}

Lumbar spinal ganglia of $G$. domesticus (Hybro) on the 10th and 18th days of incubation and 8th, 35th, 61st and 120th post-hatching days were used. The ganglia were removed from the hatched chicks immediately after ether anesthesia and from the embryos after decapitation. Ganglia fragments were fixed by $2.0 \%$ gluteraldehyde in $0.1 \mathrm{M}$ cacodylate buffer ( $\mathrm{pH} 7.2 ; 480 \mathrm{mOsm})$ até $4.0 \circ \mathrm{C}$ for $2 \mathrm{~h}$ and postfixed for $1 \mathrm{~h}$ by $1 \%$ osmium tetroxide in $0.05 \mathrm{M}$ phosphate buffer with $123 \mathrm{mg} / \mathrm{ml}$ sucrose at $4 \circ \mathrm{C}$. After a quick rinse in phosphate buffer, the fragments were dehydrated with cthanolpropylene oxide and embedded in araldite.

The diameter of 200 nuclear transections (for each animal) of spinal ganglia neurons were measured with a filar micrometric eyepiece (Kplx8, with an oil immersion objective $\times 100$ ) in $0.5 \mu \mathrm{m}$ methylene blue - azur II stained sections *. Considering the neuron nuclei as having a spherical shape, the mean radius was estimated by the Bach 2 method. The corresponding numerical processings were performed by a suitably programmed HP-9810A electronic calculator. The absolute nuclear volumes were finally obtained from the formula for the sphere.

The relative volume of cytoplasm was evaluated in 100 microscopic fields for each animal, counting points lying on nuclei and cytoplasm with a Zeiss 100-point integrating (Kplx8) and oil immersion objective (x100). These data and those of the nuclear volume enabled us to obtain the absolute cytoplasmic volume.

The ultrastructural morphometric evaluations were carried out using an 84-segment text system (based on Weibel et al.58) superimposed in two orthogonal directions on 20 electronmicrophotographs ** $(\mathrm{x} 21,000)$ for each animal, taken at random over the ganglia fragments.

The data obtained by counting of points on cytoplasmic constituents (RER, SER, mitochondria, dense bodies, Golgi complex and hyaloplasm inside and outside the Nissl bodies) and intersections with contours of transected organelle membranes enabled us to estimate the relative volume $\left(\mathrm{V}_{\mathrm{vi}}\right)$ of these constituents, the surface-to-volume ratio $\left(s_{i} / v_{i}\right)$ and the total surface $\left(S_{t o t}\right)$ of the organelles. The following formulas were used:

$$
v_{v i}=\frac{P_{i}}{P_{t}} ; s_{i} / v_{i}=\frac{4 \cdot N_{i}}{Z \cdot P_{i}} ; s_{t o t}=s_{v i} \cdot v: s_{v i}=\frac{4 \cdot N_{i}}{Z \cdot P_{t}} .
$$

were $P_{i}=$ differential counting of points: $P_{t}=$ total number of points; $N_{i}=$ number of intersections over transected organelle membranes; $\mathbf{Z}=$ enlargement factor; $\mathbf{S}_{\mathbf{v} \mathbf{i}}=$ surface density; $\mathrm{V}=$ cytoplasmic absolute volume.

The mean values of 3 specimens used for each age are presented in table 1.

* Performed in a Ultratome LKB uitramicrotome, donated by the FAPESP (Processo 70/1445).

** Photographed in a EM-9 of the Laboratory of Electronmicroscopy (Prof. Dr. Antonio Sesso) - Department of Pathology of the São Paulo Medical School - São Paulo University (Brasil). 


\section{RESULTS}

The estimated data are presented in Table 1 and, graphically in figures 1 and 2. The changes of the histological characteristics observed in our material are similar to thuse observed by Hamburger and Levi-Montalcini 22. On the 18th day of incubation the two until then distinct groups of neurons are already intermingled, showing different sizes and staining intensities (Fig. 3). As one can see in table 1 and figure 1. the mean cell volume increases constantly, particularly between the 1st and the 2nd ages keeping the following proportions among themselves: $1.0: 13.5: 12.5: 24.1$ : $23.8: 30.2$, respectively on the 10th and 18th days of incubation and on the 8 th, 35th, 61st, and 120th post-hatching days. A particularly intense increase between the 1st and the 2nd ages was observed for the relative and the absolute cytoplasmic volume. The variations of nuclear volume occurred according to the following proportions: $1.0: 3.5: 2.4: 3.5: 3.0: 2.6$. The nuclear cytoplasmic ratio decreased uniformely: $16.3: 3.1: 2.2: 1.7: 1.4: 1.0$.

The electronmicroscopic morphometric study showed an increase of relative volume of RER and a decrease of SER immediately before hatching. Later on, the relative volume of SER (except on the 120th day) increased and those of RER decreased. Except for the 1st age, the absolute volume of RER presented relatively small

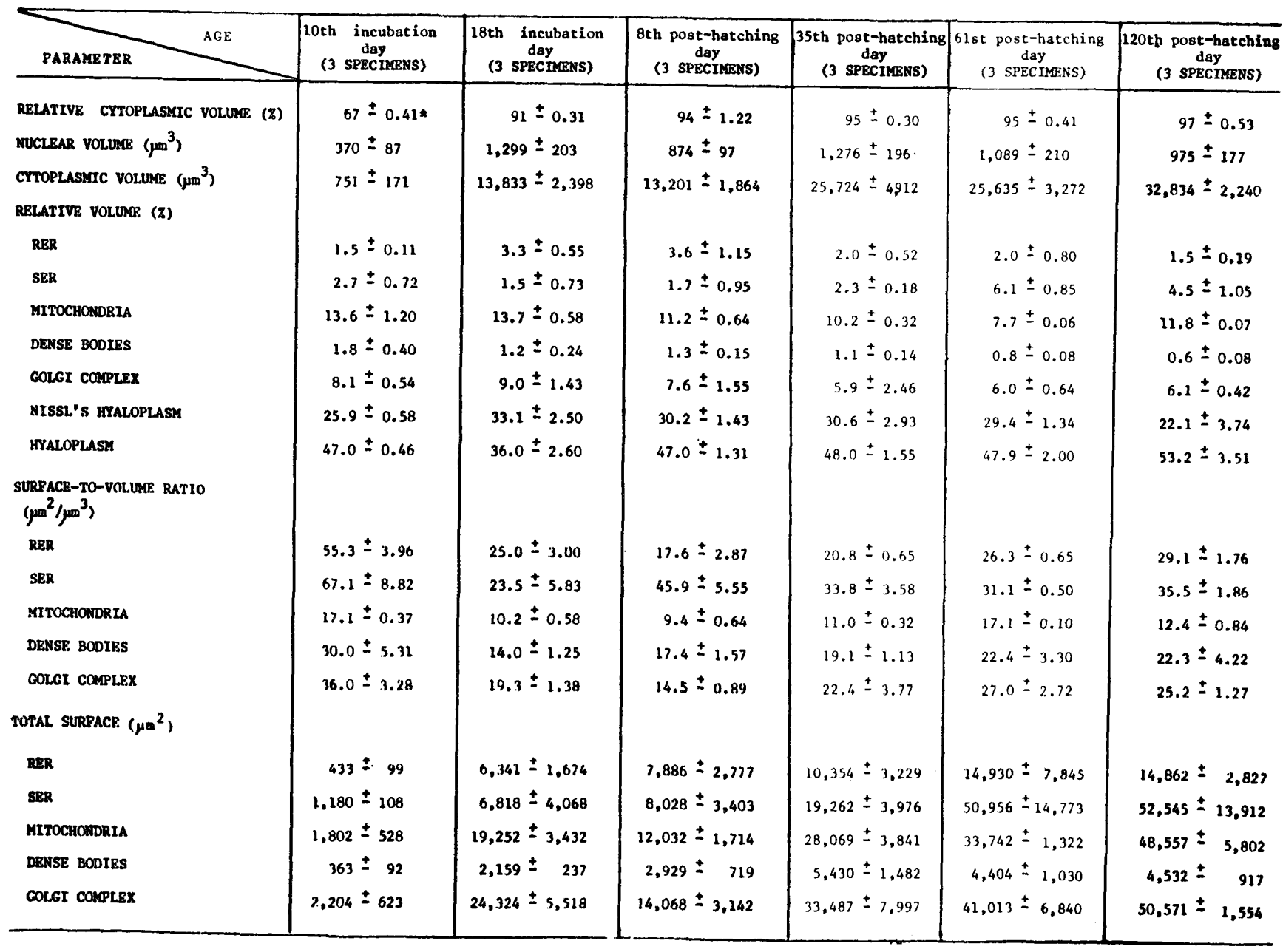

*standard error of tie viean

Table 1 - Changes of nuclear and cytoplasmic (RER, SER, mitochondria, dense bodies, Golgi complex, hyaloplasm and Nissl's hyaloplasm) volume, and of surface-to-volume ratio and total surface of the same organelles in lumbar spinal ganglia cell bodies of Gallus domesticus on the 10 th, 18 th adys of incubation, 8th, 35th, 61st and 120th post-hatching days. 


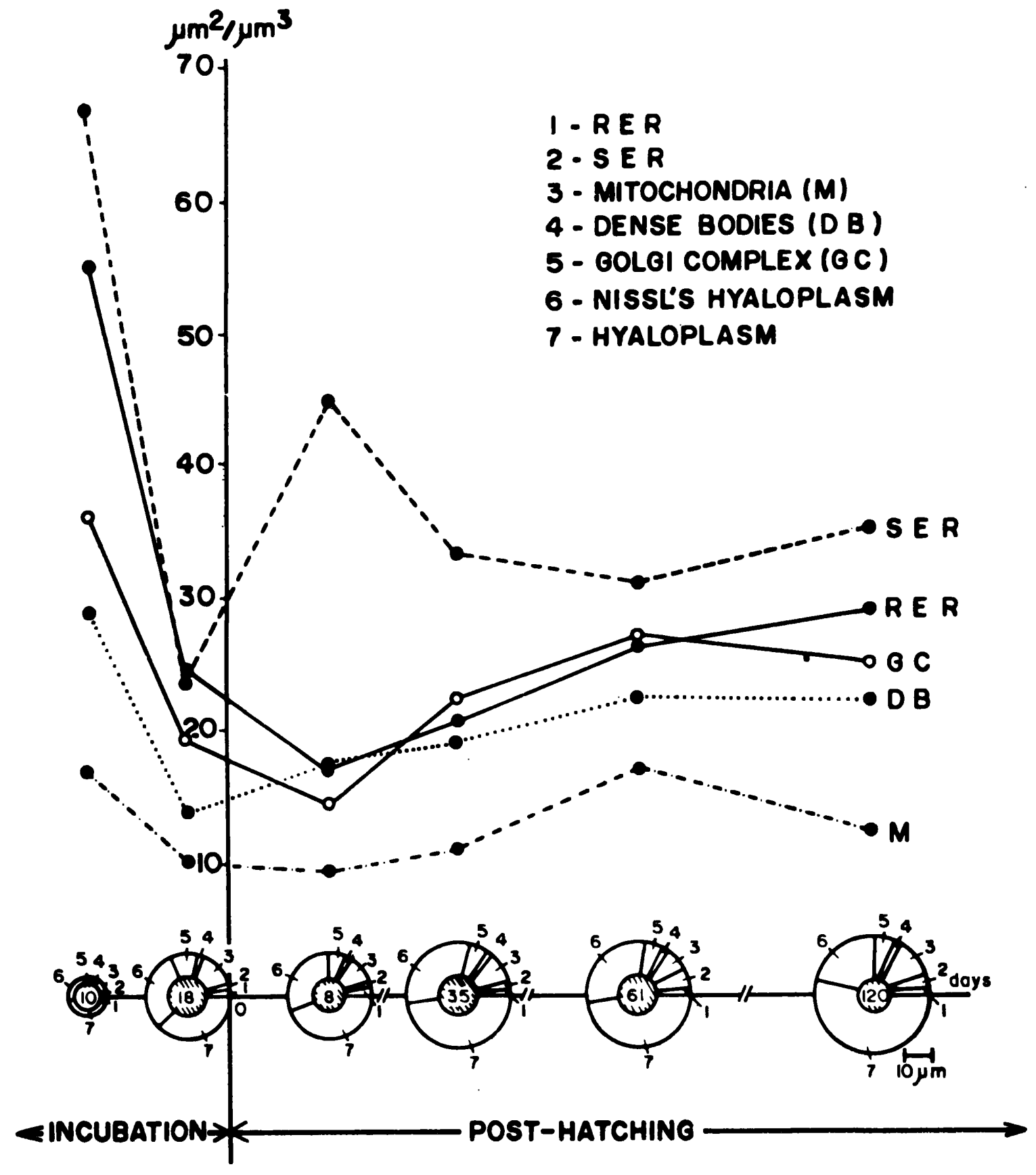

Eig. 1 - Variations of surface-to-volume ratio ( $\mu \mathrm{m} 2 / \mu \mathrm{m} 3)$ of $R E R, 8 E R$, mitochondria, dense bodies and Golgi complex in perikarion of lumbar spimal ganglia neurons of G. domesticus in 6 ages (days). The corresponding relative volumes of the organelles and hyaloplasm inside and outside the Nissl bodies are represented in the abscissa. 
variations, decreasing slightly on the 120th day $(8 \pm 0.8-459 \pm 76-473 \pm 152-$ $514 \pm 134-518 \pm 205-496 \pm 62 \mu \mathrm{m} 3)$. On the other hand, the absolute volume of SER increased dramatically $(20 \pm 5-213 \pm 101-224 \pm 125-579$ $\pm 46-1,574 \pm 218-1,478 \pm 345 \mu \mathrm{m} 3)$. The relative volume of Golgi complex decreases from the 2nd to the 4th age, then becoming stable. The mitochondria (except for the 120th day) and dense bodies show a progressive decrease of the same parameter.

The behavior of the hyaloplasm inside and outside the Nissl bodies with respect to relative volume is the opposite; with the exception of the 10th day of incubation, the relative volume of Nissl hyaloplasm drops, while the absolute volume of this constituent grows until the 35th day, decreasing slightly afterwards (194 $\pm 4-4,575$ $\left.\pm 346-3,987 \pm 189-7,882 \pm 754-7,544 \pm 344-7,252 \pm 1,228 \mu^{\mathrm{m} 3}\right)$. The surface-to-volume ratio drops sharply for all organelles from the 10th to the 18th day of incubation. After hatching, a tendency to increase was observed. Total surface also grows sharply between the first two ages. Intense growth of total surface of SER on the 61st and 120th day is observed, together with a slight increase of those of dense bodies and none of RER between the last two ages, in spite of the great increase of the absolute cytoplasmic volume. However, the changes in total surface can be better understood in terms of variations of the membrane surface-to-cytoplasmic volume ratios $\left(s_{\text {tot }} / V\right)$ (table 2$)$. These sequences show a decrease of membrane $/ \mu \mathrm{m} 3$ of cytoplasm from the 10 th to the 18 th days of incubation. After hatching, the ratio increases for mitochondria, Golgi complex, and particularly for SER, in the last two ages, while it decreases for dense bodies and alternates for RER according to the proportion $1.5: 1.1$.

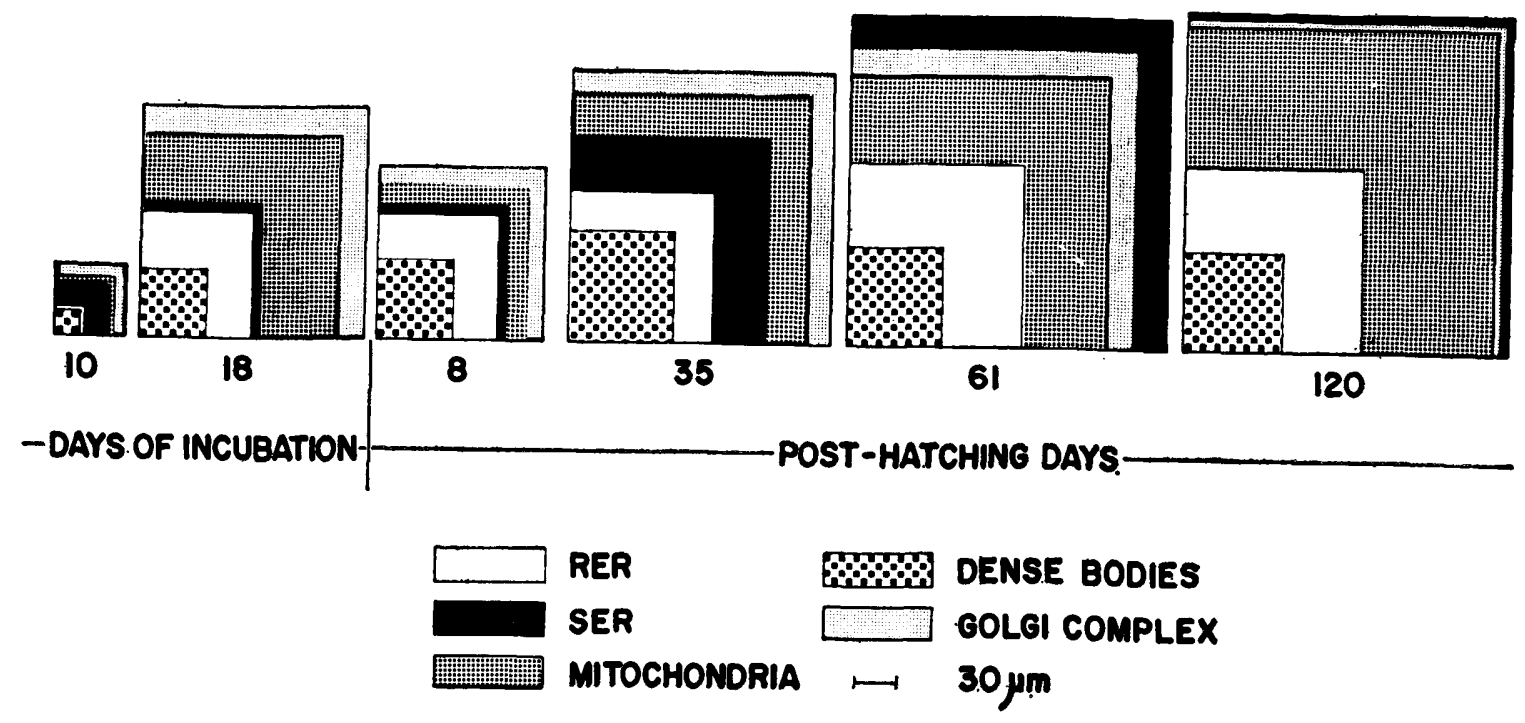

Fig. 2 - Variations of total surface of $R E R, S E R$, mitochondria, dense bodies, and Golgi complex in perikarion of lumbar spinal ganglia neurons of G. domesticus in 6 ages (days). 

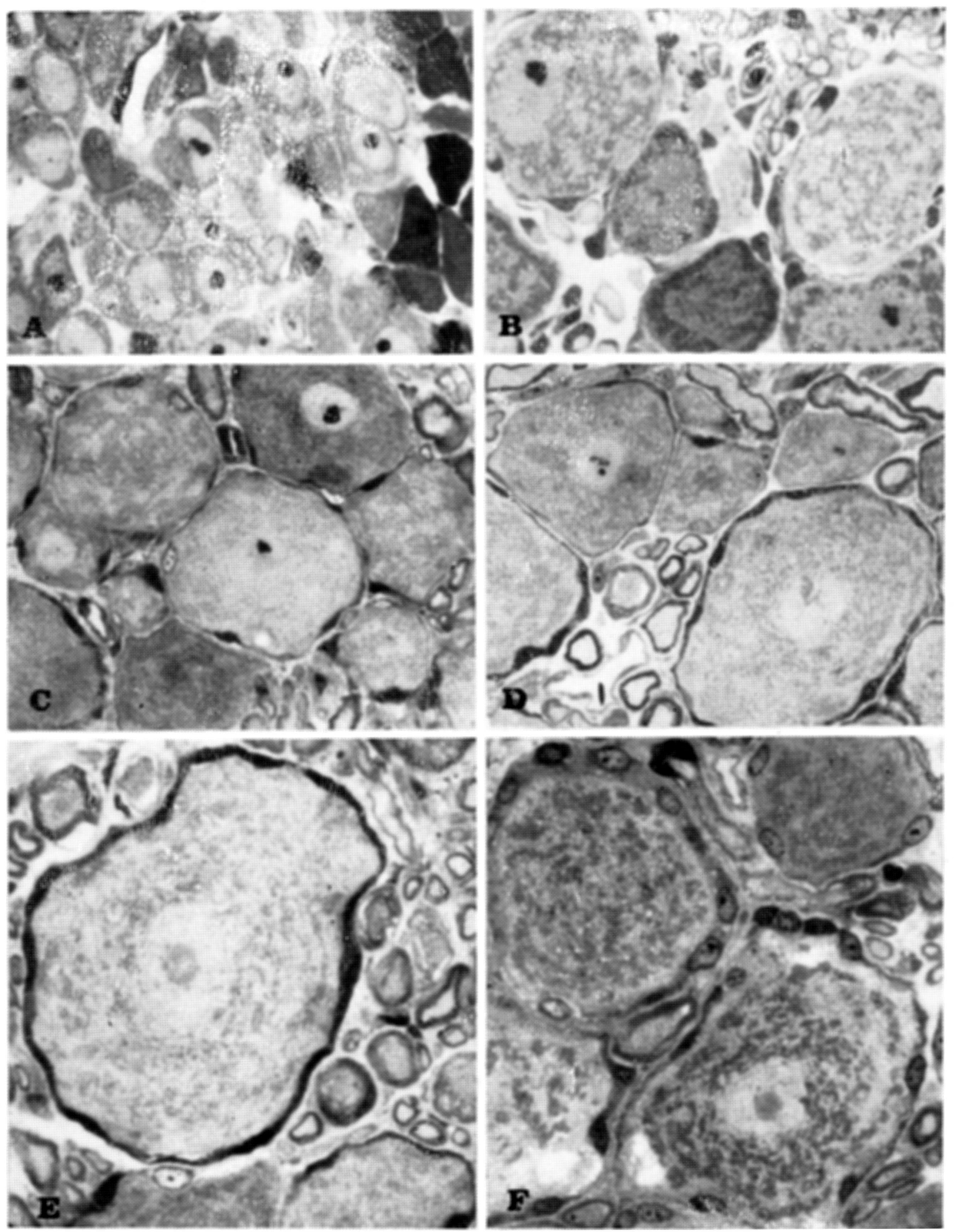

Fig. $3-1 \mu m$ thick araldite sections of lumbar spinal ganglia neurons of G. domesticus stained by methylene blue-azur II: $A$ and $B$ (respectively on the 10th and 18th days of incubation); $C, D, E, F$ (respectively on the 8th; 35th, 61st and 120th post-hatching days); xy0. 


\begin{tabular}{|c|c|c|c|c|c|c|}
\hline \multirow{2}{*}{ 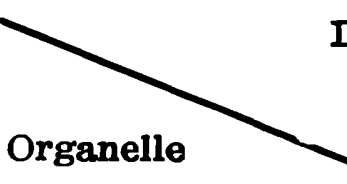 } & \multicolumn{2}{|c|}{ Incubation } & \multicolumn{4}{|c|}{ Post-Hatching } \\
\hline & 10th & 18th & 8 th & 35th & 61st & 120th \\
\hline RER & 1.5 & 1.1 & 1.5 & 1.0 & 1.5 & 1.1 \\
\hline SER & 3.2 & 1.0 & 1.2 & 1.5 & 4.1 & 3.3 \\
\hline Mitochondria & 2.6 & 1.5 & 1.0 & 1.2 & 1.5 & 1.7 \\
\hline Dense bodies & 3.4 & 1.1 & 1.6 & 1.5 & 1.2 & 1.0 \\
\hline Golgi complex & 2.7 & 1.7 & 1.0 & 1.2 & 1.5 & 1.4 \\
\hline
\end{tabular}

Table 2 - Sequence of the proportions of the organelle membrane surface-to-cytoplasmic volume ratios.

\section{COMMENTS}

Regarding neuron growth in the spinal ganglia of $G$. domesticus, our findings are equivalent to those of Olivo et al. ${ }^{40}$; these authors found a marked growth during the embryonic period which decreases immediately after hatching, while increasing progressively even after 6 months. We observed significant growth in cell volume between the 1st and 2nd ages, with a slight decrease on the 8th post-hatching day and continuous growth during all other ages.

Except for the last age, the positive ratio between nuclear and cell body sizes observed by Hatai ${ }^{23}$ was confirmed by our findings. Based on Levi's 30 suggestions, Donaldson and Nagasaka ${ }^{12}$ and Ohta et al. 39 correlated cell size and innervation field during the post-natal development, in order to explain the continuous growth of the sensory neurons, months after hatching. It is generally assumed that the control the periphery exerts on differentiating ganglia is chemical in nature and is transmitted to the cell bodies by retrograde axonal flow in peripheral nerve fibers $26,27,36$.

Concerning the cytoplasmic constituents specifically, Fujita and Fujita 10, Pannese ${ }^{46,47}$ and Tennyson ${ }^{57}$ studied the development of the various organelles (RER, SER, Golgi complex) from the neuroblastic to the neuronal period, reporting a particularly intense increase in number of the mitochondria ${ }^{47}$. Our estimates regarding the organelle development of the cell body start during the neuronal period. We observed an increase in the relative volume of RER and Golgi complex during the incubation periods, a decrease in those of SER and dense bodies, and no modification in mitochondria.

According to Pannese et al. ${ }^{44,45}$ the acetylcholinesterase (AChE) activity increases considerably in the pseudounipolar nerve cell when compared to the primitive neuroblast, being parallel to the development of RER and the Golgi complex. AChE-activity in sensory ganglia cells could be considered as one of the most important events characterizing their biochemical differentiation. A relationship between the increase in AChE and the development of RER would be supported by our morphometric data and Giacobini et al.'s ${ }^{20}$ findings; they 
pointed out an activity raise from the 6th to the 12th day of incubation, a progressive decrease to the minimum value by the time of hatching, and a slight increase in the following two days.

The opposite bahavior of the RER and SER concerning the relative volume could be dependent on the specific role of this kind of cell. The proteins synthesized by the neuron would be greatly used for the biochemical turnover of cell body constituents and of the axon 16,17,20. On the other hand, the Nissl bodies ergastoplasm differs cleary from that of the high-production protein-exporting gland cells. Palay and Palade 42 and Peters et al. 48 have reported numerous free ribosomes among the ER-cysternae; the membrane-attached ribosomes do not present a uniform distribution pattern along the cysternae and it is not difficult to demonstrate a continuity of RER with SER in nerve cells. More than $98 \%$ of the proteins of nerve endings would be synthesized by RER, reaching the nerve endings by fast axonal flow 16,17,29 where SER plays the most important role. The increase of relative volume and total surface of SER in the cell body seems to emphasize this role.

As a consequence of the diffuse character and continuity with RER and cell surface, the SER would be the ideal structure for a fast spread of substances from the site of their synthesis or capture. According to different authors the proteins, glycoproteins, or phospholipids would be transported by the SER from the cell body to the nerve endings $6,8,9,14,15,17,18,33,53,56$. SER is involved in the origin of microvesicles and the transport of substances to mitochondria and axolemma (including the presynaptic plasma membrane 13,14,17) and from the perikaryon towards the axon ${ }^{14}$. SER is also an important pathway for substance transport from the nerve endings towards the cell body 37,54 . The changes of relative volume of Golgi complex and RER are similar. The Golgi complex of the nerve cell plays an important role in the synthesis of glycoproteins $5,25,38,41,55$. On the other hand changes of relative volume of mitochondria are slight, when compared to the other constituents. Apparently the mitochondria are distributed at random in the perikaryon among the Nissl bodies in the so-called 'Plasmastrassen' 1 or 'roads' 7 where they seem to move ${ }^{49}$, probably aided by microtubuli and microfilaments ${ }^{3}$. These considerations suggest uniform physiological role of mitochondria in different cell parts. Under the designation 'dense bodies' we can consider different structures such as the lysosomal complex, melanin (neuromelanin) and lipofuscin-containing pigment bodies; however, they are related to one another and to mitochondria, Golgi complex and RER 48 .

In sensory ganglia cells literature data refer to an age-associated increase in lipofuscin bodies $21,35,52$ and lysosomes ${ }^{32}$ and the presence of very scarce melanin granules 4,11. According to our findings the dense bodies in G. domesticus showed a gradual and constant decrease of relative volume at least for the period between the 10th day of incubation and the 120th post-hatching day. 


\section{SUMMARY}

A cytomorphometric study was performed in lumbar spinal ganglia neurons of Gallus domesticus on the 10th and 18th incubation days and 8th, 35th, 61st, and 120th post-hatching days. The absolute volume of nucleus and relative volume of cytoplasm were respectively estimated by the Bach 2 caryometric method and by point-counting volumetry, carried out in $0.5 \mu \mathrm{m}$ thick araldite sections. The relative volume, the surface-to-volume ratio and the total surface of RER, SER, mitochondria, dense bodies, Golgi complex and the relative volume of hyaloplasm inside and outside the Nissl bodies were estimated from electronmicrographs by the Weibel et al. 58 method. The conclusions were: a) there was an increase of the cell volume and a decrease of the nucleocytoplasmic ratio, particularly between the first two ages; b) the relative volumes of RER and SER change inversely with respect to each other: the RER increases before hatching, decreasing progressively afterwards; the changes of relative volume of dense bodies are similar to those of the RER, and the mitochondria show relatively small variations concerning the same parameter; c) the relative volume of hyaloplasm inside the Nissl bodies decreases while those outside increases; d) the surface-to-volume ratio drops sharply for all organelles from the 10th to the 18th day of incubation; after hatching, a tendency to increase is observed; e) the membrane surface-to-cytoplasmic volume ratio decreases for all organelles from the 10th to the 18th day of incubation; after hatching, this ratio increases slightly for mitochondria and Golgi complex, sharply for SER, dropping for dense bodies. The RER values alternate regularly.

\section{RESUMO}

Estudo morfométrico sobre corpos de células nervosas de gânglios espinais lombares de Gallus domesticus antes e depois da eclosão.

Foi realizado estudo citomorfométrico em neurônios de gânglios espinais lumbares de Gallus domesticus no $10^{\circ}$ e $18^{\circ}$ dias de incubação e no $8^{\circ}, 35^{\circ}, 61^{\circ}$ e $120^{\circ}$ dias após a eclosão. Os volumes absoluto do núcleo e relativo do citoplasma foram estimados, respectivamente, pelo método cariométrico de Bach ${ }^{2}$ e pela volumetria de contagem de pontos, em cortes de araldite de $0.5 \mu \mathrm{m}$. O volume relativo, a relação superfície/volume e a superfície total do RER e SER, mitocôndria, corpos densos, complexo de Golgi e volume relativo de hialoplasma, no interior e fora dos corpos de Nissl, foram estimados a partir de eletron-micrografias, pelo método de Weibel et al. 58. As conclusōes foram: a) l:ouve aumento do volume celular e diminuição da relação núcleo-citoplasmática, particularmente entre as duas primeiras idades; b) os volumes relativos do RER e SER variam inversamente, entre si: o RER aumenta antes da eclosão, decrescendo, após, progressivamente; as variações do volume relativo dos corpos densos são semelhantes àquelas do RER e as mitocôndrias mostram relativamente, pequenas variações, no que concerne ao mesmo parâmetro; c) o volume relativo do hialoplasma no interior dos corpos de Nissl 
diminui, enquanto o situado no interior, aumenta; d) a relação superfície/volume decresce muito para todas as organelas, do $10^{\circ}$ para $018^{\circ}$ dia de incubação; após a eclosão foi observada tendência à elevação; e) a relação superfície de membrana volume citoplasmático cai para todas as organelas, do $10^{\circ}$ para o $18^{\circ}$ dia de incubação; após a eclosão, esta relação diminui levemente para mitocôndrias e complexo de Golgi, fortemente para o SER, caindo, também, para corpos densos. Os valores do RER alternam-se, regularmente.

\section{REFERENCES}

1. ANDRES, K. H. - Untersuchungen ueber den Feinbau von Spinalganglien. $Z$. Zellforsch. 55:1, 1961.

2. BACH, G. - Ueber die Bestimmung von charakeristischen Grupen einer Kugelverteilung aus der Verteilung der Schnittkreise. Z. Wiss. Mikroskok. mikrosk. Tech. 65 :285, 1963.

3. BARONDES, S. H. - Axoplasmic transport: a report of an NRP work session. Neurosc. Res. Prog. Bull. 5:307, 1967.

4. BEAVER, D. L.; MOSES, H. L. \& GANOTE, C. E. - Electron microscopy of the trigeminal ganglion. II. Autopsy study of human ganglia. Arch. Pathol. 79:557, 1965.

5. BENNETT, G.; LEBLOND, C. P. \& HADDAD, A. - Migration og glycoprotein from the Golgi apparatus to the surface of various cell types as shown by radioautoghaphic after labeled fucose injection into rats. J. cell. Biol. 60:258, 1974.

6. BENNETT, G.; DI GIAMBERARDINO, L.; KOENIG, H. L \& DROZ, B. - Axonal migration of protein and glycoprotein to nerve endings. II. Radioautographic analysis of the renewal of glycoproteins in nerve endings of chicken ciliary ganglion after intracerebral injection of $(3 \mathrm{H})$ fucosa and $(3 \mathrm{H})$ glucosamine. Brain Res. 60:129, 1973.

7. BUNGe, M. B.; BUNGE, R. P.; PETERSON, E. R. \& MURRAY, M. R. - A light and electron microscope study of long-term organized cultures of rat dorsal root ganglia. J. cell. Biol. 32:439, 1967.

8. BYERS, M. R. - Structural correlates of rapid axonal transport: evidence that microtubules may not be directly involved. Brain Res. 75:97, 1974.

9. CUENOD, M.; BOESCH, J.; MARKO, P.; PERISIC, M.; SANDRI, C. \& SCHONBACH. J. - Contributions of axoplasmic transport to synaptic structures and functions. Int. J. Neurosci. 4:77, 1972.

10. DAWSON, F. M.; HOSSACK, J. \& WYBURN, G. M. - Observations on the Nisgl's substance, cytoplasmic filaments and the nuclear membrane of spinal ganglion cells. Proc. R. Soc. Lond. (Biol) 144:132, 1955.

11. DE CASTRO, F. - Sensory ganglia of the cranial and spinal nerves. Normal and pathological. In Penfield, w. (ed.) - Cytology and Cellular Pathology of the Nervous System. Vol. 1. Hoeber, New York, 1932.

12. DONALDSON, H. H. \& NAGASAKA, G. - On the increase in the diameters of nerve cell bodies and of the fibers arising from them during the later phases of growth (albino rat). J. comp. Neurol. 29:529, 1918.

13. DROZ, B.; KOENNIG, H. L.; DI GIAMBERARDINO, L.; COURAUD, J. Y.; CHRETIEN, M. \& SOUYRI, F. - The importance of axonal transport and endoplasmic reticulum in the function of cholinergic synapse in normal and pathological condition. Prog. Brain Res. 49:23, 1979.

14. DROZ, B.; RAMBOURG, A. \& KOENIG, H. L. - The smooth endoplasmic reticulum: structure and role in the renewal of axonal membrane and synaptic vesicles by fast axonal transport. Brain Res. 93:1, 1975. 
15. DROZ, B.; KOENIG, H. L. \& RAMBOURG, A. - Transport intracytoplasmique de macromolécules et réticulum endoplasmique lisse: cas du flux axonal rapide. J. Microsc. 20:45, 1974.

16. DROZ, B.; KOENIG, H. L. \& DI GIAMBERARDINO, L. - Axonal migration of protein and glycoproteins to nerve endings. I Radioautographic analysis of the renewal of proteins in nerve endings of chick ciliary ganglion after intracerebral injeçtion of (H3) lysine. Brain Res. 60:93, 1973.

17. DROZ, B. - Renewal of synaptic proteins. Brain Res. 62:383, 1973.

18. DROZ, B. \& KOENIG, H. L. - Localization of protein metabolism in neuron. In Lajtha A. (ed.) - Protein Metabolism of the Nervous System. Plenum Press, New York, 1970.

19. FUJITA, H. \& FUJITA, S. - Electron microscopic studies on neuroblast differentiation in the central nervous system of domestic fowl. Z. Zellforsch. 60:463, 1963.

20. GIACOBINI, G.; MARChisio, P. C.; GIACOBINI, E. \& kOSLOW, S. H. Developmental changes of cholinesterases and monoamine oxidase in chick embryo spinal and sympathetic ganglia. J. Neurochem. 17:1177, 1970.

21. GLEES, P. \& GOPINATH, G. - Age changes in the centrally and peripherally located sensory neurons in rat. Z. Zellforsch. 141:285, 1973.

22. HAMBURCER, V. \& LEVI-MONTALCINI, R. - Proliferation, differentiation and degeneration in the spinal ganglia of the chick embryo under normal and experimental conditions. J. exp. Zool. 111:457, 1949.

23. HATAI, S. - A study of the diameters of the cells and nuclei in the second cervical spinal ganglion of the adult albino rat. J. comp. Neurol. 17:469, 1907.

24. HESS, A. - The fine structure of nerve cells and fibers neuroglia and sheaths of the ganglion chain in the cockroach (Periplaneta americana). J. biophys. biochem. Cytol. 4:731, 1958.

25. HOLTZMAN, E.; TEICHBERG, S.; ABRAHMS, S. J.; CITKOWITZ, E.; CRAIN, S. M. ; KAWAI, N. \& PETERSON, E. R. - Notes on synaptic vesicles and related structures, endoplasmic reticulum, lysosomes and peroxisomes in nervous tissue and adrenal medulla. J. Histochem. Cytochem. 21:349, 1973.

26. HUGHES, A. F. \& CARR, V. Mc M. - The interaction of periphery and center in the development of dorsal root ganglia. In Jacobson M. - Handbook of Sensory Physiology: Development of Sensory Systems. Vol. IX. Springer, New York, 1978.

27. HUGHES, A. F. - The growth of embryonic neurites. A study on cultures of chick neural tissues. J. Anat. 87:150, 1953.

28. JOHNSTON, M. C. - A radioautographic study of the migration and rate of cranial neural crest cells in the chick embryo. Anat. Rec. 156:143, 1966.

29. KOENIG, H. L.; DI GIAMBERARDINO, L. \& BENNETT, G. - Renewal of proteins and glycoproteins of synaptic constituents by means of axonal transport. Brain Res. 62:413, 1973.

30. LEVI, G. - I gangli cerebrospinale. Studi di istologia comparata e di istogenesi. Arch ital. Anat. Embriol 7: (supplemento) 1, 1908.

31. LEVI, G. - Studi sulla grandezza delle cellule: Ricerche comparative sulla grandezza delle cellule dei mammiferi. Arch. ital. Anat. Embriol. 5:291, 1906.

32. LIEBERMAN, A. R. - The axon reaction: a review of the principle features of perikaryal responses to axon injury. In Pfeiffer C. C. and Smythies J. R. International Review of Neurobiology. Vol 14. Academic Press, London, 1971.

33. MARKOV, D.; RAMBOURG, A. \& DROZ, B. - Smooth endoplasmic reticulum and fast axonal transport of glycoproteins, an electron microscope radioautographic study of thick sections after heavy metals impregnation. J. Microsc. Biol. Cell. $25: 57,1976$. 
34. McKINNISS, M. E. - The number of ganglion cells in the dorsal root ganglia of the second and third cervical nerves in human fetuses of various ages. Anat. Rec. $65: 255$, 1936.

35. MOSES, H. L. ; BEAVER, D. L. \& GANOTE, C. E. - Electron microscopy of the trigeminal ganglion: comparative ultrastructure. Arch. Pathol, 79:541, 1965.

36. NAKAI, J. - Dissociated dorsal root ganglia in tissue culture. Amer. J. Anat. $99: 81,1956$.

37. NAUTA, H. J. W.; KAISERMAN - ABRAMOF, I. R. \& LASEK, R. J. - Electron microscopic observations of horseradish peroxidase transported from the caudoputamen to the substantia nigra in the rat: possible involvement of the agranular reticulum. Brain Res. 85:373, 1975.

38. NOVIKOFF, P. M. ; NOVIKOFF, A. B.; QUINTANA, N. \& HAUW, J. J. - Golgi apparat: s, GERL and lysosomes of neurons in rat dorsal root ganglion, studies by thick section and thin section cytochemistry. J. cell. Biol. 50:859, 1971.

39. OHTA, M.; OFFORD, K. \& DYCK, P. J. - Morphometric evaluation of first sacral ganglia of man. J. neurol. Sci. $22: 73,1974$.

40. OLIVO, O. M.; PORTA, E. \& BARBERIS, L. - Modalità di accrescimento delle cellule e degli organi. IV. Modalità di accrescimento delle cellule dei gangli spinali nel pollo durante la vita embrionale e postnatale. Arch. ital. Anat. Embriol. 30:34, 1932.

41. OSINCHAK, J. - Electron microscopic localization of acid phosphatase and thyamine pyrophosphatase activity in hypothalamic neurosecretory cells of the rat. $J$. cell. Biol. 21:35, 1964.

42. PALAY, S. L. \& PALADE, G. E. - The fine structure of neurons. J. biophys. biochem. Cytol. 1:69, 1955.

43. PANNESE, E. - The histogenesis of the spinal ganglia. Adv. Anat. Embryol. cell. Biol. $47: 6,1974$.

44. PANNESE, E.; LUCIANO, L.; IURATO, S. \& REALE, E. - The localization of acetyl cholinesterase activity in the spinal ganglia of the adult fowl studied by electron microscope histochemistry. Histochemistry 39:1, 1974.

45. PANNESE, E.; LUCIANO, L.; IURATO, S. \& REALE, E. - Cholinesterase activity in spinal ganglia neuroblasts: a histochemical study at the electron microscope. J. ultrastruct. Res. 36:46, 1971.

46. PANNESE, E. - Developmental changes of the endoplasmic reticulum and ribosomes in nerve cells of the spinal ganglia of the domestic fowl. J. comp. Neurol. $132: 331,1968$.

47. PANNESE, E. - Expansive growth of the nuclear envelope and formation of mitochondria in ganglionic neuroblast. Z. Zellforsch. 72:295, 1966.

48. PETERS, A.; PALAY, S. L. \& WEBsTER, H. de F. - The Fine Structure of the Nervous System: the Neurons and Supporting Cells. W. B. Saunders Co., Philadelphia, 1976.

49. POMERAT, C. M.; HANDELMAN, W. J.; RAIBORN, C. W. \& MASSEY, J. F. - Dynamic activities of nervous tissue in vitro. In Hydén, $H$. - The Neuron. Elsevier, Amsterdam, 1967.

50. ROSENBLUTH - Subsurface cisterns and their relationship to the neuronal plasma membrane. J. cell. Biol. 13:405, 1962.

51. ROSENBLUTH, J. - The fine structure of acoustic ganglia in the rat. $J$. cell. Biol. 12:329, 1962.

52. SAMORAJSKI, T.; ORDY, J. M. \& RADY-REIMER, P. - Lipofucsin pigement accumulation in the nervous system of ageing mice. Anat. Rec. 160:555, 1968.

53. SCHONBACH, J.; SCHONBACH, C. \& GUNOD, M. - Rapid phase of axoplasmic flow and synaptic proteins: an electron microscopical autoradiographic study. J. comp. Neurol. $141: 485,1971$. 
54. SOTELO, C. \& RICHE, D. - The smooth endoplasmic reticulum and the retrograde and fast orthograde transport of horseradish peroxidase in the nigrostriato-nigral loop. Anat. Embryol. 146:209, 1974.

55. SOTELO, C. \& PALAY, S. L. - Altered axons and axon terminals in the lateral vestibular nucleus of the rat: possible example of axonal remodelling. Lab. Invest. $25: 653,1971$.

56. TAXI, J. \& SCTELO, C. - Cytological aspects of the axonal migration of catecholamines and of storage material. Brain Res. 62:431, 1973.

57. TENNYSON, V. M. - Electron microscopic study of the developing neuroblast of the dorsal root ganglion of the rabbit embryo. J. comp. Neurol. 124:267, 1965.

58. WEIBEL, E. R.; KISTLER, G. S. \& SCHERLE, W. F. - Practical stereological methods for morphometric cytology. J. cell. Biol. 30:23, 1966.

59. WESTON, J. A. - The migration and differentiation of neural crest cells. Adv. Morphol. 8:41, 1970.

60. WESTON, J. A. \& BUTLER, S. L. - Temporal factors affecting localization of neural cells in chicken embryo. Dev. Biol. 14:246, 1966.

61. WESTON, J. A. - A radioautographic analysis of the migration and localization of trunk neural crest cells in the chick. Dev. Biol. 6:279, 1963.

Departamento de Amatomia - ICB - Bloco 30 - Universidade de são Paulo Caixa Postal 4365 - 01000 são Paulo, SP - Brasil. 